\title{
Keinginan untuk Membayar Pembiayaan Kesehatan Pemerintah Kota pada Masyarakat Mampu di Kota Bandung
}

\author{
Nita Arisanti, Henni Djuhaeni, Sharon Gondodiputro, Elsa Pudji Setiawati, Guswan Wiwaha, \\ Insi Farisa Desy Arya, Fedri R Rinawan \\ Departemen Ilmu Kesehatan Masyarakat, Fakultas Kedokteran Universitas Padjadjaran
}

\begin{abstract}
Abstrak
Pembiayaan kesehatan diselenggarakan dengan prinsip ekuitas, artinya penduduk yang mampu akan membayar iuran/ premi secara penuh, dan masyarakat miskin dibayarkan oleh pemerintah. Banyak faktor yang memengaruhi keinginan untuk membayar (WTP). Penelitian ini bertujuan mendapatkan gambaran keinginan masyarakat mampu membayar pembiayaan kesehatan dan faktor-faktor yang memengaruhinya. Penelitian kuantitatif dilakukan pada Agustus - September 2011 terhadap 303 kepala keluarga yang tergolong masyarakat mampu di Kota Bandung. Mampu dalam penelitian ini adalah penduduk tinggal di perumahan elite. Kriteria inklusi yaitu kepala keluarga, memiliti KTP Kota Bandung, bersedia diwawancara. Teknik pemilihan sampel menggunakan cluster sampling, dengan klaster adalah perumahan elit di Kota Bandung. Subjek di tiap klaster ditentukan secara proporsional systematic sampling. Analisis data menggunakan distribusi frekuensi dan regresi logistik. Dari 303 responden, 54,9\% yang memiliki asuransi, tidak ingin membayar dan 60\% yang belum memiliki, ingin membayar pembiayaan kesehatan Pemkot Bandung. Sebagian besar masyarakat mampu hanya ingin membayar premi kurang dari Rp. 25.000 dengan berharap mendapatkan semua jenis pelayanan kesehatan. Agama dan pendidikan terakhir merupakan faktor yang menentukan secara bermakna keinginan membayar pembiayaan kesehatan. Rendahnya kesadaran responden untuk ikut serta program pembiayaan kesehatan Pemkot Bandung harus dapat diantisipasi pemerintah dengan lebih mendorong masyarakat dari semua golongan status sosial - ekonomi untuk mengikuti program pembiayaan kesehatan.
\end{abstract}

Kata Kunci: Keinginan, Kesehatan, Masyarakat mampu, Pembiayaan

\section{Willingness to Pay of High Income Population to Health Insurance in Bandung District}

\begin{abstract}
Health financing aims to protect and maintain people meet the basic needs of health. This effort is organized nationally by the principle of equity. Equity means there is sharing contribution from the have to the poor. The objective of this study was to determine the willingness to pay of high-income population to health insurance in Bandung district and identify the predictors. Crosssectional study was performed with sample size of 303. High income population was choosen by cluster sampling. The number of subject in each cluster is determined proportionate to size and drawn by systematic sampling in each cluster. Logistic regression was used to analyze the data. From 303 respondents, 54.9\% have insurance but not willing to pay and $60 \%$ who do not have insurance are willing to pay to health insurance. Most of respondents were willing to pay health insurance premiums not more than Rp. 25,000 to access all type of health care. Religion and education level are strong predictors for willingness to pay. Lack of awareness from the respondents to participate in health financing in Bandung should be anticipated by the government to further raise awareness and encourage people from all social-economic status to pay health-financing.
\end{abstract}

Keywords : Health insurance, High-income, Population, and willingness

Korespondensi:

Nita Arisanti, dr., MSc-FM

Departemen Ilmu Kesehatan Masyarakat, Fakultas Kedokteran Universitas Padjadjaran

Jl. Prof. Dr. Eykman No. 38 Bandung 40161

Mobile : 08122386276

Email : nitarully@gmail.com 


\section{Pendahuluan}

Penyelenggaraan upaya kesehatan dilakukan dengan prinsip kemitraan antara pemerintah, masyarakat, dan swasta karena pemerintah tidak mungkin dapat membiayai upaya kesehatan karena keterbatasan pendapatan. Universal Coverage (UC) atau jaminan semesta bertujuan agar masyarakat mendapat akses pelayanan kesehatan sesuai kebutuhannya. Masyarakat merupakan salah satu komponen sistem pembiayaan kesehatan, baik sebagai pelaku maupun sasaran. Pembiayaan kesehatan untuk menjamin terpelihara dan terlindunginya masyarakat dalam memenuhi kebutuhan dasar kesehatan diselenggarakan dengan prinsip ekuitas artinya bahwa bagi penduduk yang mampu akan membayar iuran/premi secara penuh, bagi penduduk yang setengah mampu akan membayar sebagian dan bagi masyarakat miskin dibayarkan oleh pemerintah. Salah satu ukuran yang adil dalam pendanaan kesehatan adalah beban pendanaan kesehatan dari perorangan tidak memberatkan penduduk artinya seseorang mampu mendapatkan pelayanan sesuai dengan kebutuhan medisnya dan membayar sesuai dengan kemampuan membayarnya. ${ }^{1}$

Keinginan untuk membayar pembiayaan kesehatan (willingness to pay, WTP) lebih menekankan pada nilai yang dianut dan menggambarkan perilaku seseorang. Asumsinya adalah bahwa setiap orang atau rumah tangga akan membuat keputusan yang rasional dalam menggunakan sumber daya yang dimilikinya. ${ }^{2}$ WTP yang menggambarkan kemauan seseorang atau rumah tangga untuk membayar pelayanan tersebut dihitung dari pengeluaran atau expenditure-nya untuk kesehatan. ${ }^{1}$ Banyak faktor yang memengaruhi WTP, antara lain umur, jenis kelamin, suku bangsa, status pernikahan, status sosial-ekonomi seperti tingkat pendidikan, pekerjaan, pendapatan, perilaku masyarakat, persepsimasyarakatterhadappelayanankesehatan, kepesertaan asuransi kesehatan sebelumnya dan tingkat kesehatan masyarakat itu sendiri. ${ }^{3}$

Kota Bandung sebagai ibukota Provinsi Jawa Barat dengan jumlah penduduk menurut BPS sebesar 2.414.704 jiwa dan jumlah KK sebesar 721.929, belum semua penduduknya terlindungi oleh pembiayaan kesehatan. Untuk mengetahui seberapa besar keinginan masyarakat untuk mengikuti pembiayaan kesehatan dengan membayar premi diperlukan suatu kajian. Tujuan penelitian ini adalah didapatkannya gambaran tentang keinginan masyarakat mampu untuk membayar pembiayaan kesehatan pemerintah Kota Bandung dan faktor-faktor yang memengaruhinya.

\section{Metode}

Disain penelitian adalah kuantitatif. Responden merupakan kepala keluarga yang tergolong masyarakat mampu di Kota Bandung. Dianggap mampu karena tinggal di perumahan elit/ real estate. Kriteria inklusi yaitu kepala keluarga, memiliki Kartu tanda Penduduk Kota Bandung, sedangkan kriteria eksklusi adalah saat dikunjungi tidak ada ditempat atau menolak ikut serta dalam penelitian. Berdasarkan perhitungan sampel didapatkan 303 kepala keluarga menjadi responden yang diambil secara cluster sampling. Klaster adalah perumahan elite di Kota Bandung. Berdasarkan data dari pemerintah kota, rerdapat empat belas klaster perumahan elit di Kota Bandung. Jumlah subjek ditentukan secara proporsional dari masing-masing klaster dan responden diambil secara systematic sampling di tiap klaster. Pengambilan data menggunakan kuesioner yang telah dilakukan uji validitas dan reliabilitas. Kemudian dilakukan analisis data dengan menggunakan distribusi frekuensi dan regresi logistik. Penelitian ini dilakukan pada bulan Agustus sampai dengan September 2011.

\section{Hasil}

Dari 389 responden, hanya 303 kepala keluarga yang bersedia mengikuti penelitian ini (response rate $=79 \%$ ). Berikut gambaran keinginan untuk membayar pembiayaan kesehatan Pemerintah Kota Bandung.

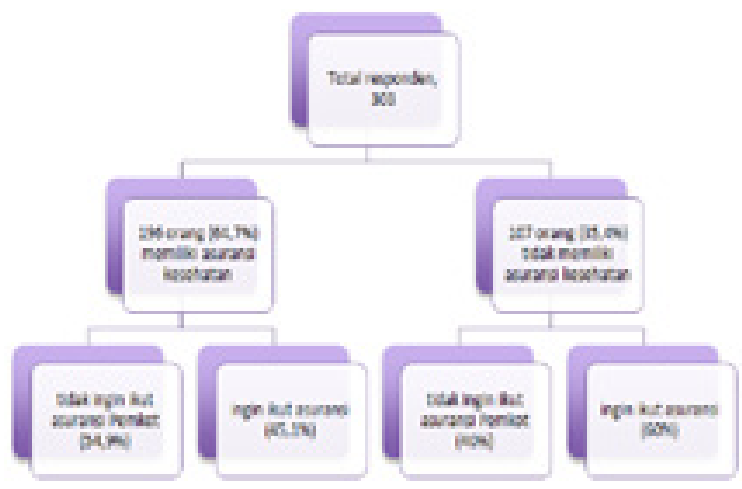

\section{Gambar 1 Gambaran keinginan masyarakat mampu untuk membayar pembiayaan kesehatan Pemerintah Kota Bandung.}

Responden yang sudah memiliki asuransi kesehatan, 54,9\% tidak ingin membayar pembiayaan kesehatan Pemkot Bandung dengan alasan belum merasa perlu untuk mengikutinya. Sebesar $40 \%$ responden yang belum memiliki asuransi kesehatan, tidak ingin membayar 
pembiayaan kesehatan Pemkot Bandung dengan alasan bahwa asuransi kesehatan sosial ini belum jelas aturannya dan saat ini tidak perlu asuransi.

Sebagian besar responden yang merupakan kepala keluarga mempunyai pekerjaan sebagai karyawan swasta. Dilihat dari rata-rata total penghasilan seluruh anggota keluarga per bulan adalah Rp. 7.650.000, dengan minimal penghasilan $\mathrm{Rp} 300.000$ dan maksimal $\mathrm{Rp}$ 75.000.000. Penghasilan ini mempunyai peran yang bermakna dalam menentukan keinginan seseorang untuk membayar pembiayaan kesehatan. Selain karakteristik responden, penelitian ini juga menggambarkan kepemilikan asuransi kesehatan. Sebanyak $64,7 \%$ reponden sudah memiliki asuransi kesehatan dengan jenis asuransi yang dimiliki adalah ASKES, Jamsostek, Prudential, Manulife dan Bumiputera.

Hasil kajian juga menggambarkan harapan dan keinginan dari 151 orang yang ingin membayar pembiayaan kesehatan Pemkot Bandung baik yang sudah memiliki maupun yang belum memiliki pembiayaan kesehatan. Sebagian besar masyarakat mampu hanya ingin membayar

Tabel 1 Karakteristik Responden

\begin{tabular}{|c|c|c|c|}
\hline \multicolumn{2}{|c|}{ Karakteristik } & \multirow{2}{*}{$\frac{\text { Jumlah }}{144}$} & \multirow{2}{*}{$\frac{\text { Persentase (\%) }}{47,5}$} \\
\hline Jenis Kelamin & Laki-laki & & \\
\hline & Perempuan & 159 & 52,5 \\
\hline \multirow[t]{5}{*}{ Usia (tahun) } & $15-24$ & 15 & 5 \\
\hline & $25-34$ & 58 & 19,3 \\
\hline & $35-44$ & 73 & 24,3 \\
\hline & $45-54$ & 65 & 21,6 \\
\hline & Diatas 55 & 90 & 29,9 \\
\hline \multirow[t]{5}{*}{ Agama } & Islam & 216 & 72,5 \\
\hline & Kristen & 41 & 13,8 \\
\hline & Katolik & 35 & 11,7 \\
\hline & Hindu & 1 & 0,3 \\
\hline & Budha & 5 & 1,7 \\
\hline \multirow[t]{6}{*}{ Pendidikan terakhir } & SD & 7 & 2,3 \\
\hline & SMP & 11 & 3,6 \\
\hline & SMA & 96 & 31,7 \\
\hline & Perguruan Tinggi & 183 & 60,5 \\
\hline & Lainnya (Diploma) & 5 & 1,6 \\
\hline & Tidak menjawab & 1 & 0,3 \\
\hline \multirow[t]{4}{*}{ Status Perkawinan } & Kawin & 253 & 83,8 \\
\hline & Belum kawin & 22 & 7,3 \\
\hline & Duda/ janda & 26 & 8,6 \\
\hline & Tidak menjawab & 2 & 0,6 \\
\hline \multirow[t]{9}{*}{ Pekerjaan KK } & PNS & 44 & 14,6 \\
\hline & Karyawan/ti swasta & 95 & 31,7 \\
\hline & Pedagang & 40 & 13,4 \\
\hline & Jasa & 24 & 8 \\
\hline & Lainnya & & \\
\hline & Pensiunan & 46 & 14,8 \\
\hline & Wiraswasta & 43 & 14,2 \\
\hline & IRT & 8 & 2,3 \\
\hline & Tidak menjawab & 3 & 1 \\
\hline
\end{tabular}




\begin{tabular}{llcc}
\hline Karakteristik & & Jumlah & Persentase (\%) \\
\hline Anggota keluarga yang ditanggung (orang) & 1 & 71 & 23,4 \\
& $2-4$ & 192 & 63,4 \\
& $5-7$ & 24 & 7,9 \\
& Lebih dari 7 & 4 & 1,3 \\
\multirow{3}{*}{ Status kepemilikan rumah } & Tidak menjawab & 12 & 4 \\
& Milik sendiri & 188 & 62 \\
& Rumah keluarga & 70 & 23,1 \\
& Sewa/ kontrak & 27 & 8,9 \\
Sarana transportasi & Tidak menjawab & 18 & 5,9 \\
& Kendaraan milik & 262 & 86,5 \\
& sendiri & & 0,7 \\
& Kendaraan sewa & 2 & 6,3 \\
Kepemilikan pembiayaan kesehatan & Kendaraan umum & 19 & 6,6 \\
& Tidak menjawab & 20 & 64,7 \\
& Ya & 196 & 34,7 \\
& Tidak & 105 & 0,7 \\
\hline
\end{tabular}

Tabel 2 Gambaran Keinginan dan Harapan terhadap Program Pembiayaan Pemerintah Kota Bandung

\begin{tabular}{lcc}
\hline \multicolumn{1}{c}{ Karakteristik } & Jumlah & Persentase (\%) \\
\hline Besar premi yang dibayar (Rp/ orang) & 59 & 39,1 \\
$<25.000$ & 34 & 22,5 \\
$25.000-50.000$ & 31 & 20,5 \\
$50.000-75.000$ & 25 & 16,6 \\
$>75.000$ & 2 & 1,3 \\
Tidak menjawab & & \\
Jenis pelayanan kesehatan minimal yang diinginkan & 130 & 86,1 \\
Semua pelayanan rawat jalan, rawat inap, laboratorium dan operasi & 12 & 7,9 \\
Pelayanan rawat jalan, rawat inap dan laboratorium & 8 & 5,3 \\
Rawat jalan saja & 2 & 0,7 \\
Tidak menjawab & & \\
Tempat pelayanan kesehatan yang diinginkan & 65 & 43 \\
Fasilitas pelayanan kesehatan pemerintah & 85 & 56,3 \\
Fasilitas pelayanan kesehatan swasta & 1 & 0,7 \\
Tidak menjawab & & \\
Proses pembayaran iuran kesehatan (premi) & 16 & 10,6 \\
Bersamaan dengan iuran RT/RW & 1 & 0,7 \\
Bersamaan dengan pembayaran sampah & 25 & 16,6 \\
Bersamaan dengan pembayaran rekening listrik & 6 & 4 \\
Melalui pajak (SPT) yang dibayar sendiri & & \\
\hline
\end{tabular}




\begin{tabular}{lcc}
\hline \multicolumn{1}{c}{ Karakteristik } & Jumlah & Persentase (\%) \\
\hline Melalui tabungan khusus untuk kesehatan yang dikelola pemerintah & 33 & 21,9 \\
Pembayaran langsung ke badan asuransi pemerintah & 63 & 41,7 \\
Lainnya & 5 & 3,3 \\
Tidak menjawab & 2 & 1,2 \\
Periode pembayaran iuran kesehatan (premi) & & \\
Setiap bulan & 105 & 69,5 \\
Tiga bulan sekali & 19 & 12,6 \\
Enam bulan sekali & 7 & 4,6 \\
Dibayar sekaligus satu tahun & 18 & 11,9 \\
Tidak menjawab & 2 & 1,4 \\
Waktu pembayaran iuran kesehatan (premi) & & \\
Awal bulan & 90 & 59,6 \\
Tengah bulan & 29 & 19,2 \\
Akhir bulan & 12 & 7,9 \\
Awal tahun & 11 & 7,2 \\
Tengah tahun & 1 & 0,7 \\
Akhir tahun & 6 & 4 \\
Tidak menjawab & 2 & 1,4 \\
Bentuk kartu keanggotaan peserta asuransi wajib sosial Pemkot & & \\
Bandung & & \\
Kartu khusus & 107 & 70,9 \\
KTP berlogo asuransi & 39 & 25,8 \\
Lainnya & 2 & 1,3 \\
Tidak menjawab & 3 & 2 \\
Kesediaan membayar premi pembantu dll & & \\
Ya, seluruhnya & 52 & 34,4 \\
Ya, sebagian & 21 & 13,9 \\
Tidak & 24 & 15,9 \\
Tidak menjawab & 54 & 35,8 \\
\hline & & \\
\hline
\end{tabular}

premi asuransi kesehatan sebesar kurang dari Rp. 25.000 dengan harapan mendapatkan semua jenis pelayanan kesehatan baik rawat jalan, rawat inap, laboratorium bahkan operasi. Selain itu, responden berharap mendapatkan pelayanan bukan hanya di sarana milik pemerintah, tetapi juga di sarana milik swasta. Jika dilihat dari rata-rata penghasilan yang dimiliki responden yaitu sebesar Rp. 7.500.000, hal ini menandakan kesadaran responden untuk membayar pembiayaan kesehatan pemerintah masih sangat rendah. Banyak faktor yang memengaruhi keinginan seseorang untuk membayar pembiayaan kesehatan. Dalam penelitian ini didapatkan gambaran faktor-faktor yang berpengaruh pada kelompok yang sudah memiliki dan yang belum memiliki pembiayaan kesehatan.
Tabel 3 Faktor-faktor yang berpengaruh terhadap keinginan membayar Pembiayaan Kesehatan Pemerintah Kota Bandung pada kelompok yang sudah memiliki pembiayaan kesehatan

\begin{tabular}{lccc}
\hline Variabel & B & Wald & p value \\
\hline Agama & 0,608 & 7,938 & 0,005 \\
Pekerjaan KK & 0,137 & 1,744 & 0,187 \\
Usia & 0,06 & 0,168 & 0,682 \\
Pendidikan terakhir & 0,014 & 0,003 & 0,958 \\
Status Perkawinan & $-0,087$ & 0,093 & 0,761 \\
Anggota keluarga & 0,315 & 1,168 & 0,28 \\
yang ditanggung & & & \\
\hline
\end{tabular}


Agama merupakan faktor yang menentukan secara bermakna keinginan membayar pembiayaan kesehatan Pemkot Bandung.

Tabel 4 Faktor-faktor yang berpengaruh terhadap keinginan membayar Pembiayaan Kesehatan Pemerintah Kota Bandung pada kelompok yang belum memiliki pembiayaan kesehatan

\begin{tabular}{lccc}
\hline Variabel & B & Wald & p value \\
\hline Agama & 0,708 & 5,85 & 0,016 \\
Pekerjaan KK & 0,192 & 0,972 & 0,324 \\
Usia & $-0,077$ & 0,132 & 0,717 \\
Pendidikan terakhir & 0,603 & 3,584 & 0,050 \\
Status Perkawinan & 0,054 & 0,017 & 0,895 \\
Anggota keluarga & $-0,262$ & 0,435 & 0,51 \\
yang ditanggung & & & \\
\hline
\end{tabular}

Agama dan pendidikan terakhir merupakan faktor yang menentukan secara bermakna keinginan membayar pembiayaan kesehatan Pemkot Bandung.

\section{Pembahasan}

Berdasarkan penelitian didapatkan bahwa masyarakat yang mampu sekalipun belum semuanya menjadi peserta program pembiayaan kesehatan dan belum memiliki asuransi kesehatan. Sebagian besar tidak memiliki tabungan yang digunakan apabila mereka memerlukan biaya pengobatan. Pembiayaan kesehatan yang tidak memadai dapat menyebabkan meningkatnya pembiayaan out-of-pocket untuk pengeluaran kesehatan. Hal ini tidak hanya membatasi pemanfaatan pelayanan kesehatan, tetapi juga secara tidak langsung memengaruhi kesehatan dan produktivitas seseorang. ${ }^{2}$

Dari 196 responden yang telah memiliki asuransi, hanya $45,1 \%$ yang ingin membayar. $\mathrm{Hal}$ ini bertentangan dengan penelitian di Malaysia yang menunjukkan bahwa masyarakat yang sudah memiliki asuransi kesehatan lebih memiliki keinginan untuk ikut program pembiayaan kesehatan yang baru. ${ }^{4}$ Temuan ini menunjukkan bahwa pembiayaan untuk kesehatan masih bukan menjadi prioritas masyarakat mampu di Kota Bandung. Dari hasil penelitian diatas, masyarakat mampu belum cukup mengerti akan manfaat dan kegunaan dari asuransi kesehatan. Hal ini berbeda dengan beberapa penelitian yang menyebutkan bahwa semakin tinggi pendidikan dan semakin mampu keluarga, keinginan untuk membayar pembiayaan kesehatan akan semakin tinggi. ${ }^{4-8}$ Penelitian di Karibia menunjukkan bahwa status sosial ekonomi merupakan prediktor utama dalam menentukan keinginan membayar pembiayaan kesehatan. ${ }^{6}$ Selain faktor ekonomi, banyak faktor yang memengaruhi keinginan untuk membayar pembiayaan kesehatan, seperti suku bangsa, jenis kelamin, pendidikan, penghasilan dan jumlah anggota keluarga. ${ }^{4,9}$ Semakin bertambah jumlah anggota keluarga, keinginan untuk mengikuti program pembiayaan kesehatan semakin menurun. ${ }^{9}$ Pada penelitian ini faktor agama pada masyarakat yang sudah mempunyai asuransi kesehatan dan agama serta pendidikan pada masyarakat yang belum memiliki asuransi kesehatan merupakan prediktor utama dalam menentukan keinginan membayar pembiayaan kesehatan Pemkot Bandung. Hasil penelitian ini memperkuat penelitian di Afrika yang menyebutkan bahwa agama dan kepercayaan merupakan prediktor utama dalam menentukan keinginan untuk mengikuti program asuransi selain kemampuan membayar masyarakat. ${ }^{10}$ Keterbatasan penelitian ini adalah waktu pengambilan data yang tidak sesuai dengan keberadaan responden pada saat pengambilan data.

Berdasarkan hasil penelitian, disimpulkan bahwa mengetahui faktor-faktor yang memengaruhi keinginan membayar pembiayaan kesehatan adalah hal yang harus dipertimbangkan dalam memulai suatu program pembiayaan baru

\section{Ucapan Terima Kasih}

Terimakasih kami sampaikan pada Kepala Dinas Kesehatan Kota Bandung dan semua pihak yang terlibat dalam penelitian ini

\section{Daftar Pustaka}

1. Hasbullah Thabrany. Pendanaan Kesehatan dan Alternatif Mobilisasi Dana Kesehatan di Indonesia. Jakarta: PT Raja Grafindo Persada. 2005:4, 9-25.

2. Ascobat Gani. Kemampuan Membayar (Ability To Pay) dan Kebijaksanaan Tarif Pelayanan Kesehatan. Jakarta: Program Studi Pascasarjana IKM Universitas Indonesia. 2000:1-24.

3. Akhter S, Larson C.P. Willingness to pay for zinc treatment of childhood diarrhoea in a rural population of Bangladesh. Health Policy and Planning. 2010;25:230-6.

4. Shafie A.A, Hassali M.A. Willingness to pay for voluntary community-based health 
insurance: Findings from an exploratory study in the state of Penang, Malaysia. Social Science \& Medicine 96.2013:272-6.

5. Jarahi L, Karbakhsh M, Rashidian A. Parental willingness to pay for child safety seats in Mashad, Iran. BMC Public Health.2011;11(281):2-6.

6. Adams R, Chou Y, Pu C. Willingness to participate and Pay for a proposed national health insurance in St. Vincent and the grenadines: a cross-sectional contingent valuation approach. BMC Health Services Research.2015;15(148):2-10.

7. Agago TA, Woldie M, Ololo S. Willingness to Join and Pay for the Newly Proposed
Social Health Insurance Among Teachers in Wolaita Sodo Town, South Ethiopia. Ethiop J Health Sci.2014;24(3):195-202.

8. Lang HC, Lai MS. Willingness to pay to sustain and expand National Health Insurance services in Taiwan. 2008. BMC Health Services Research.2008; 8(261):1-10.

9. Nosratnejad S, et al. Willingness To Pay for Social Health Insurance in Iran. Global Journal of Health Science.2014;6(5):154-63.

10. Molla A, Fentahun N. Predictors of Willingness to Participate in Health Insurance Services Among the Community of Jimma Town, Southwest Ethiopia. Health Services Insights.2014;7:31-7. 